\title{
Histochemical, Immunohistochemical, and Ultrastructural Characteristics of Nerves in the Duvernoy's Gland of the Japanese Colubrid Snake, Rhabdophis tigrinus*
}

\author{
Sumio Yoshie, Tatsuyuki OGAWA ${ }^{1}$ and Tsuneo FuJITA ${ }^{2}$ \\ Department of Oral Anatomy ${ }^{1}$, Nippon Dental University, Niigata, and Department of Anatomy ${ }^{2}$, Niigata University School of \\ Medicine, Niigata, Japan
}

Received June 3, 1988

Summary. Nerve fibers supplying the Duvernoy's gland, a venom-secreting oral gland, of the Japanese colubrid snake, Rhabdophis tigrinus, were examined by formaldehyde-induced fluorescence (FIF) and acetylcholinesterase (AChE) histochemistry, immunohistochemistry, and electron microscopy.

The innervation by the FIF fibers was rather meager and was restricted to the area around the arteries localized in the interlobular connective tissue. The AChE-reactive fibers, in contrast, were abundantly supplied all over the gland, especially to the lobule consisting of secretory units. Peptide histidine isoleucine (PHI)(1-15)-like immunoreactive fibers were also detected in the gland and proved identical to the AChEreactive fibers. The reactivities for both AChE and PHI (1-15) were particularly prominent around the blood capillaries distributed in the lobules.

Under the electron microscope, nerve fibers were frequently seen to terminate near capillaries subjacent to the secretory unit. Those nerve terminals containing small clear vesicles and dense core granules were devoid of Schwann cell coverage on the side facing the blood capillary. These features suggest that the nerve terminals may possibly release at least a portion of their secretory contents into the blood as neurohormones.

In earlier investigations of the Japanese colubrid snake, Rhabdophis tigrinus, we found that autonomic nerves supplying the Duvernoy's gland, a venomsecreting oral gland appearing in some colubrid snakes, frequently terminate near blood capillaries. Here they include large, dense core granules presumably containing certain bioactive peptides and small, clear vesicles as well (FuJiTA et al., 1982; YoshiE et al., 1982). In the Duvernoy's gland, certain drugs such as isoproterenol, pilocarpine, and carbachol either cause an increase in the number of secretory granules or expel the granules from the secretory cells (for review, see KochVA, 1978). However, histochemical or immunohistochemical analyses on the innervation of this gland have not yet been carried out.

The present paper, therefore, describes the distribution and features of nerves using methods of acetylcholinesterase histochemistry, formaldehydeinduced fluorescence histochemistry for biogenic amines, and immunohistochemistry for some putative peptidergic innervations, i.e., vasoactive intestinal polypeptide (VIP), peptide histidine isoleucine (PHI), and substance $P$ which are widely localized in nerves supplying some mammalian salivary glands (LUND. BERG et al., 1980; POLAK and BLOOM, 1980; ROBINSON et al., 1980; UDDMAN et al., 1980; JOHANSSON and LUNDBERG, 1981; GOEDERT et al., 1982). In addition, because our previous paper on the ultrastructural features of the nerve terminals in this gland was preliminary (FUJITA et al., 1982), a thorough ultrastructural examination of the gland was also achieved in the present study.

The ultrastructural features of the nerve terminals in the Duvernoy's gland of the Japanese colubrid snake closely resembled those appearing in the endocrine portion of the pancreas of the dog (FUJITA and KOBAYASHI, 1979) and another snake, Elaphe quadrivirgata (FuJII et al., 1980). On the bases of this similarity, the present paper will discuss a possible neurosecretory function of the nerves localized around blood capillaries in the Duvernoy's gland. ${ }^{*}$ This work was supported by a Grant-in Aid for Scientific Research from the Japanese Ministry of Education, Science
and Culture (No. 56770027). 


\section{MATERIALS AND METHODS}

Ten adult Japanese colubrid snakes, Rhabdophis tigrinus, of both sexes (total length: 60-109 $\mathrm{cm}$ ) were used in this study.

\section{Formaldehyde-induced fuorescence (FIF) histochem- istry}

The method by FALCK and associates (FALCK et al., 1962) was applied for detection of catecholamines. The Duvernoy's gland was removed from anesthetized snakes, quickly frozen in a mixture of acetone and dry ice, and freeze-dried at $-40^{\circ} \mathrm{C}$ for 7 days. The dried tissue specimens were then exposed to the vapor phase of paraformaldehyde at $80^{\circ} \mathrm{C}$ for $1 \mathrm{~h}$ and embedded in paraffin. Deparaffinized sections, 10-20 $\mu \mathrm{m}$ thick, were examined with an Olympus fluorescence microscope.

The specificity control was performed by using a $0.1 \%$ sodium borohydride dissolved in $90 \%$ isopropanol as recommended by CORRODI et al. (1964). Following the application of the solution on the sections, the specific fluorescence was rapidly reduced under the fluorescence microscope.

\section{Acetylcholinesterase (AChE) histochemistry and im- munohistochemistry}

Tissue preparation: The gland was removed from anesthetized snakes, cut into small pieces, and immersed in $4 \%$ paraformaldehyde in $0.1 \mathrm{M}$ phosphate buffer, $\mathrm{pH} 7.3$ and held in the fixative for $6 \mathrm{~h}$ at room temperature. The fixed tissue specimens were then rinsed overnight in $30 \%$ sucrose in the same buffer at $4^{\circ} \mathrm{C}$ and rapidly frozen in liquid nitrogen. Sections were cut at $10-20 \mu \mathrm{m}$ on a cryostat and processed for the following histochemistry and immunohistochemistry.

AChE histochemistry: For the detection of $\mathrm{AChE}$, the method by KARNOVSKY (1964) with the substrate acetylthiocholine iodide was employed. The sections were incubated for $1 \mathrm{~h}$ at $37^{\circ} \mathrm{C}$.

Antisera: The antisera used in this investigation were as follows; rabbit anti-PHI(1-15) serum (R 8403), rabbit anti-VIP serum (R 502), and rabbit anti-substance P serum (i 675/002). Antisera of R 8403 and R 502 were generously donated by Professor N. YANAIHARA, Shizuoka College of Pharmacy, Shizuoka, Japan. The antiserum of i 675/002 was purchased commercially (UCB-Bioproducts S. A., Belgium).

Immunohistochemical protocol: Throughout the immunohistochemical investigation the peroxidase-anti- peroxidase (PAP) technique by STERNBERGER (1986) or an indirect immunofluorescence method according to Coons et al. (1955) were performed. To determine the optimum working dilution of each antiserum as a first layer, running ascending dilutions of the antisera were verified: from $1: 500$ to $1: 4,000$ and from $1: 150$ to $1: 1,200$ for the PAP and indirect fluorescence methods, respectively. For the PAP method, the sections were incubated with these antisera for $24 \mathrm{~h}$ at $4{ }^{\circ} \mathrm{C}$ followed by incubation with porcine anti-rabbit $\operatorname{IgG}(1: 20,30 \mathrm{~min})$ and rabbit PAP complex $(1: 50,30$ $\mathrm{min})$. For immunofluorescence, the sections were exposed to these antisera for $24 \mathrm{~h}$ at $4^{\circ} \mathrm{C}$, and were subsequently incubated for $1 \mathrm{~h}$ with fluorescein isocyanate (FITC)-conjugated goat anti-rabbit serum (1: 20). After examination under a fluorescence microscope, the sections were further processed for $\mathrm{AChE}$ histochemistry to determine the nature of the immunoreactive sites (if positively immunostained) in the gland.

Specificity controls: The specificity of the immunoreaction was checked by the following controls; the omission of each primary antiserum, incubating the tissue sections with normal rabbit serum in place of the primary antisera, and incubating the sections with antisera which had been preincubated for $24 \mathrm{~h}$ at $4^{\circ} \mathrm{C}$ with the corresponding antigens of $10 \mu \mathrm{g} / \mathrm{ml}$ (the antigen-inactivated antiserum). The immunohistochemical reactions followed by the control procedures were all negative.

\section{Electron microscopy}

Details of tissue preparation for electron microscopy have already been described elsewhere (YOSHIE et al., 1982). In brief, the Duvernoy's gland was perfusionfixed with $2.5 \%$ glutaraldehyde in $0.1 \mathrm{M}$ phosphate buffer at $\mathrm{pH}$ 7.4. The tissue blocks were then postfixed in $2 \%$ osmium tetroxide in the same buffer, and embedded in Epon 812. Ultrathin sections were double-stained with uranyl acetate and Reynold's lead nitrate, and examined with a Hitachi H-500 electron microscope.

\section{RESULTS}

We have already described histological details of the Duvernoy's gland in the present species under both the light and electron microscopes (OGAWA et al., 1981; FujiTA et al., 1982; YoshIE et al., 1982). In brief, the gland, located in the posterior supralabial region reaching the anglus oris posteriorly, is separated into 
Fig. 1. Formaldehyde-induced fluorescence micrograph of the Duvernoy's gland in the snake. The aminergic fibers (arrows) are associated with an artery $(A)$ in the interlobular connective tissue. Note that no fluorescence fiber occurs around the secretory units $(S)$ or collecting duct $(D) . \quad \times 270$

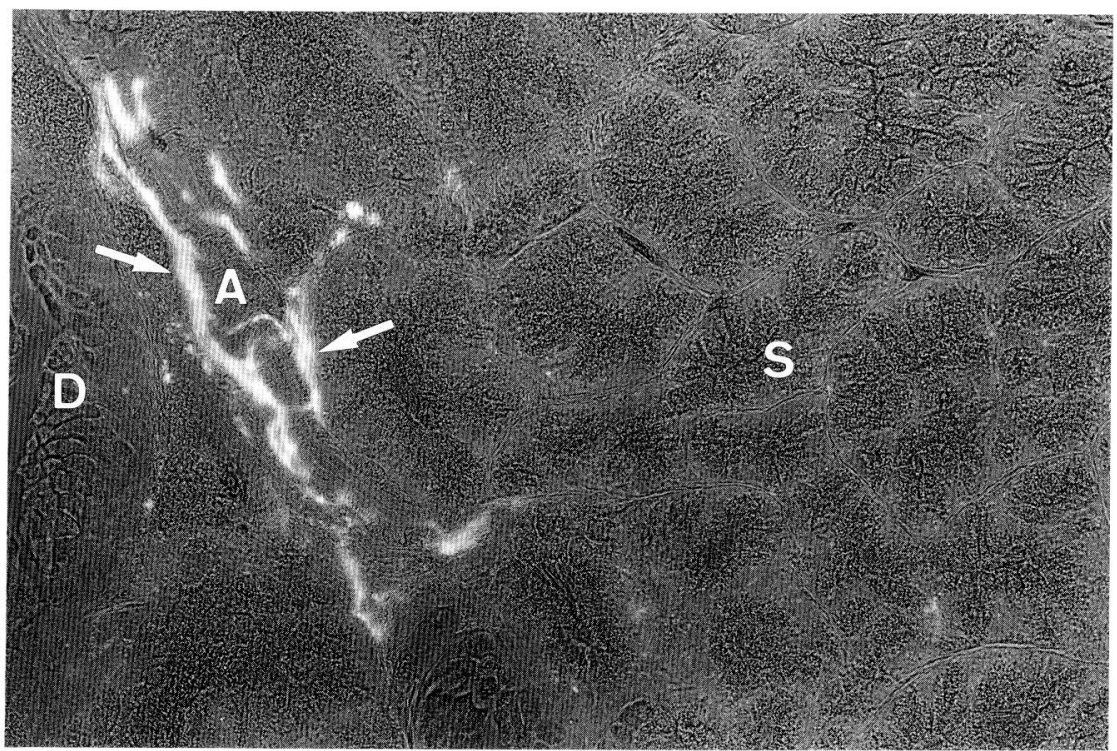

several lobules by relatively thick connective tissue, which include blood vessels and bundles of nerves. Each lobule contains tubular-shaped secretory units and collecting ducts which drain into the central duct localized in the central part of the gland body. The secretory cell consisting of secretory units is of a serous nature; both the central and collecting duct comprise high columnar mucus-secreting cells. The myoepithelial cells often enclose the secretory units. The free endings of the unmyelinated (= autonomic) nerves supply the myoepithelial cells. Furthermore, many nerve terminals end in the pericapillary space. The detailed ultrastructural features of these nerves will be described below.

\section{FIF histochemistry}

FIF histochemistry revealed the exclusive greenish blue fluorescence characteristic of catecholamine in the nerve fibers of the gland; any other element of the gland (e.g., the secretory cells, duct cells, and granulocytes in the connective tissue) was devoid of specific fluorescence for biogenic amines. The aminergic innervation by the FIF fibers was rather meager, being restricted to the area around the arteries in the interlobular connective tissue (Fig. 1). No fluorescent fibers could be found inside the lobules which contained secretory units as well as collecting ducts and thin connective tissue with small blood vessels including capillaries (Fig. 1).

\section{AChE histochemistry}

In contrast to the scarcity and restricted distribution of the aminergic fibers, AChE histochemistry showed an abundant supply of reactive fibers in both intraand extra-lobules of the gland. In the interlobular connective tissue, most of the fibers consisting of nerve bundles and those associated with blood vessels were positive for $\mathrm{AChE}$. In the lobules, on the other hand, clearly AChE-reactive fibers were observed along the thin layer of connective tissue surrounding the secretory units (Fig. 2a). The reactivity was particularly prominent around blood capillaries (Fig. 2b). The AChE-positive fibers were observed rushing toward the blood capillary. There was, however, no sign of an invasion of the nerve fibers into the secretory units.

\section{Immunohistochemistry}

Among the antisera against VIP, PHI (1-15), and substance $\mathrm{P}$ used in the present investigation, a definite immunoreactivity was exclusive for PHI (1-15) at optimum dilutions of $1: 2,000-1: 4,000$. The PHI (1 -15)-like immunoreactivity was recognized in the inter- and intra-lobular portions. Also immunoreactive were some parts of nerve fibers in a bundle which consisted mostly of AChE-positive fibers, and those fibers associated with blood vessels as well localized in the interlobular connective tissue (figures not shown). Inside the lobules, the immunoreactivity 

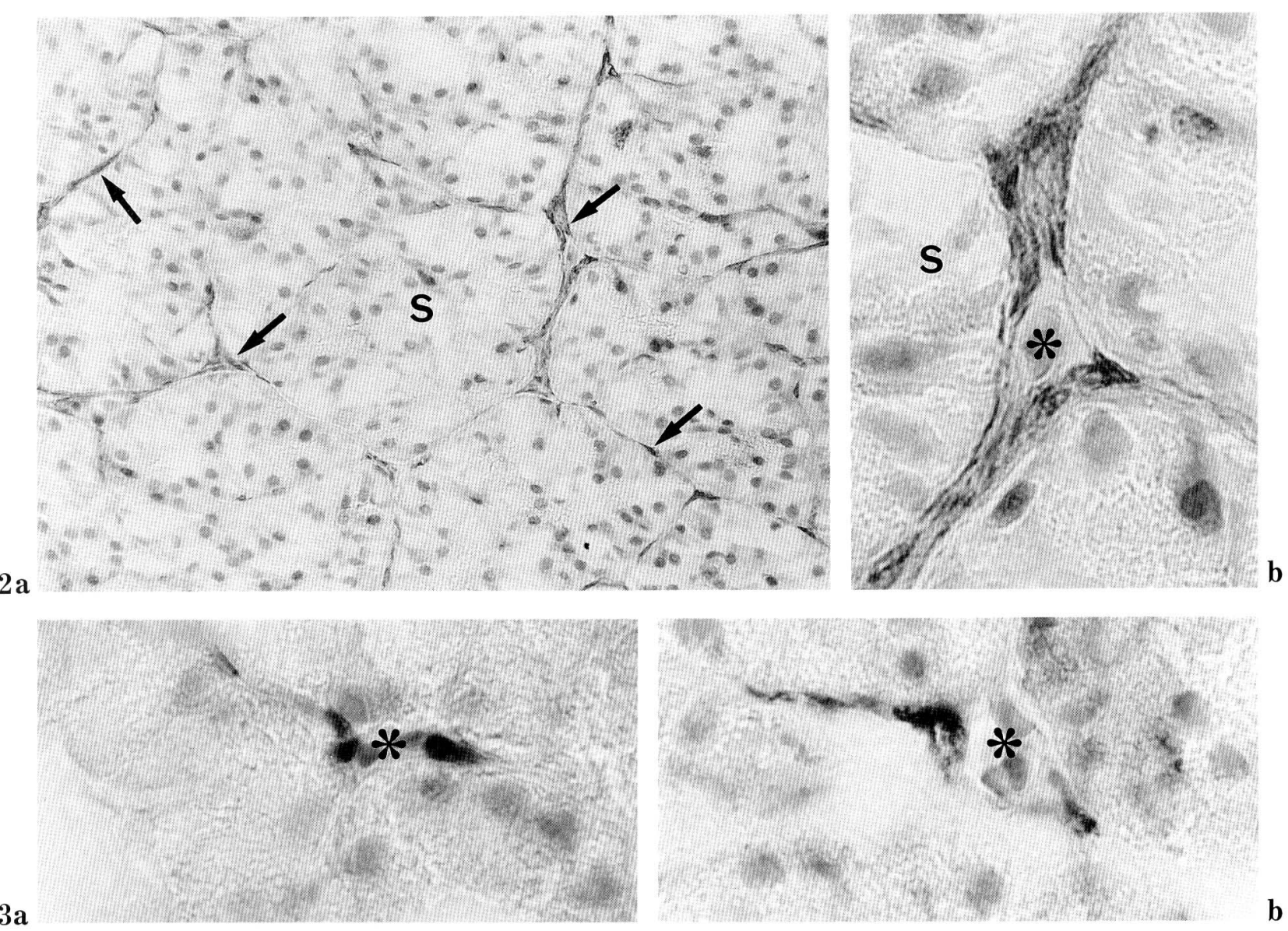

b
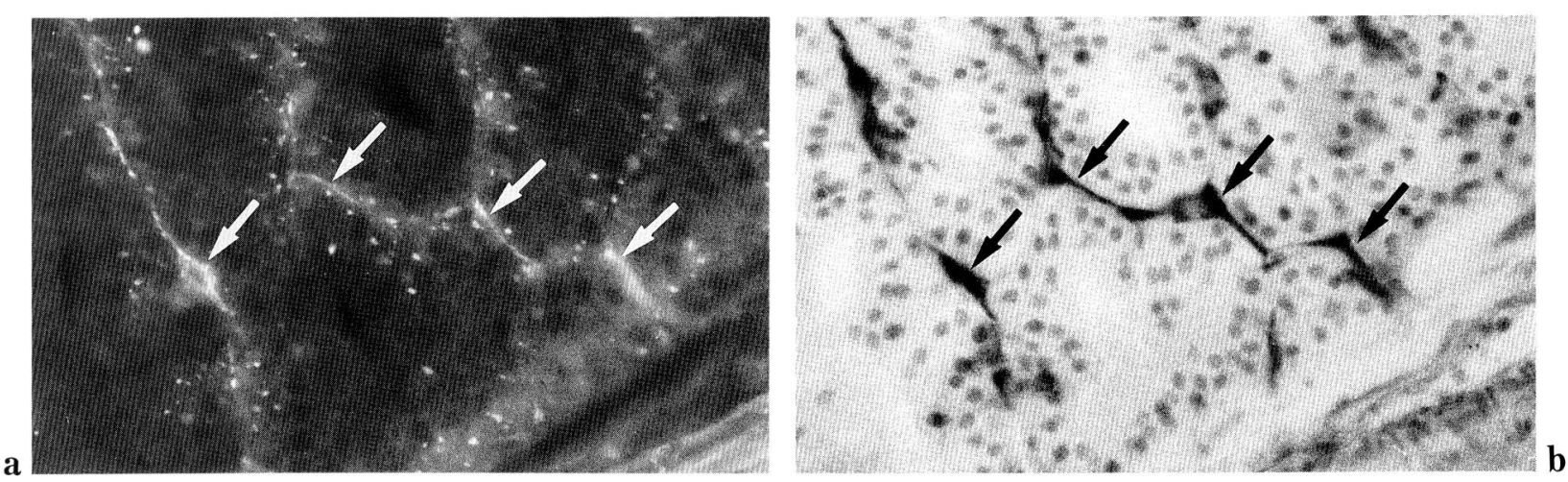

Fig. 2, a and b. AChE histochemistry of the Duvernoy's gland in the snake. a: Low magnification view of the secretory units; $\mathbf{b}$ : enlarged view of a part of $\mathbf{a}$. The reactivity is localized along the thin layer of connective tissue (arrows) surrounding the secretory units $(S)$ and is particularly prominent around a blood capillary (asterisk). Counterstained by Mayer's hematoxylin. a: $\times 300, \mathrm{~b}: \times 990$

Fig. 3, a and b. PHI (1-15)-like immunoreactivity in the snake Duvernoy's gland. Prominent immunostaining is closely related with the blood capillaries (asterisks). Counterstained by Mayer's hematoxylin. $\times 1,200$

Fig. 4, a and b. Immunofluorescence histochemistry for PHI (1-15) (a) and AChE histochemistry (b) on an identical tissue section of the Duvernoy's gland of the snake. The immunoreactive portions coincide well with the AChE reactive sites (arrows). b: Counterstained by Mayer's hematoxylin. a and b: $\times 380$ 


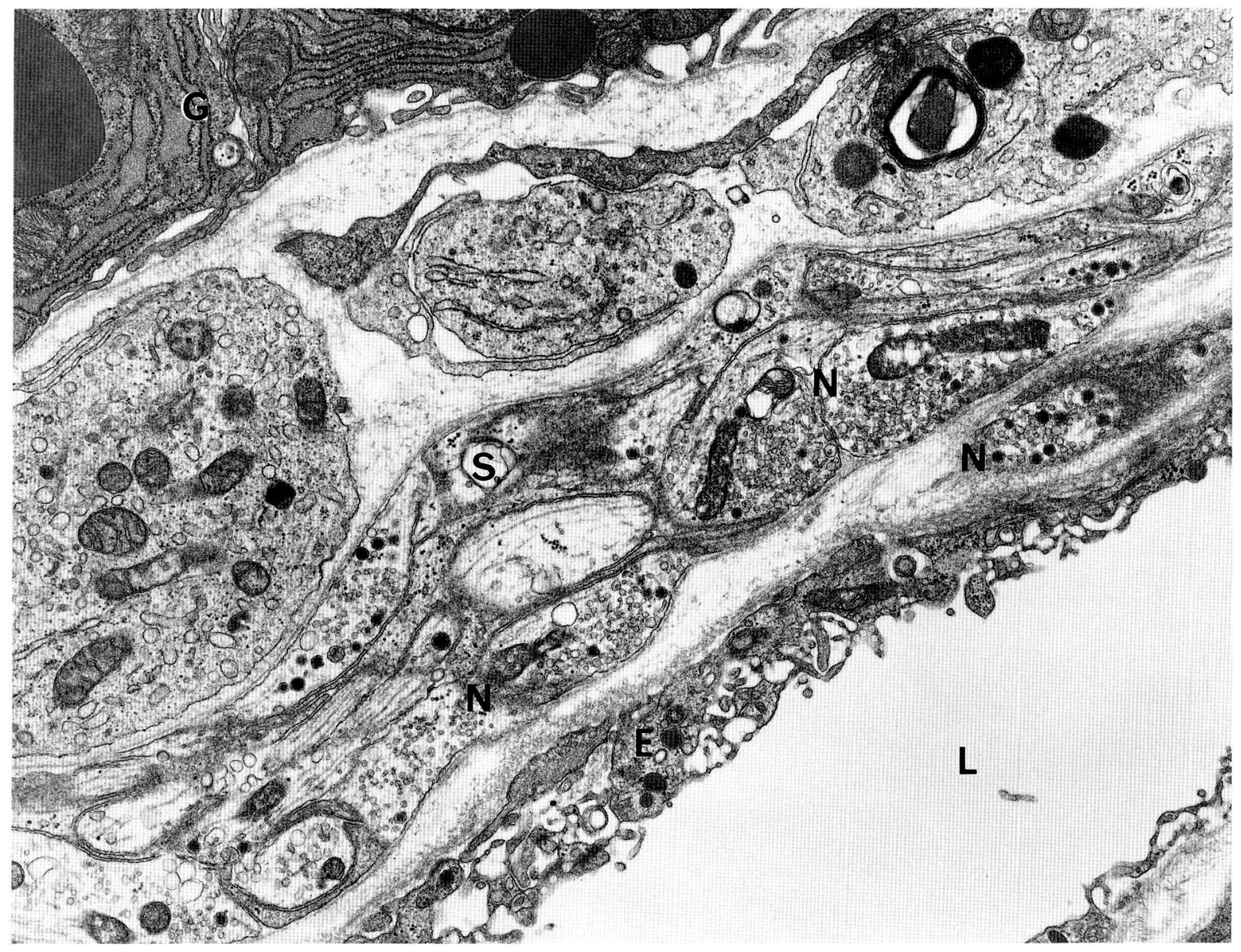

Fig. 5. Electron micrograph showing nerve fibers in a pericapillary space of the Duvernoy's gland of the snake. Axons $(N)$ containing small clear vesicles and large dense-core granules are devoid of Schwann cell $(S)$ envestments primarily on the side facing the capillary wall $(E) . \quad G$ gland cell, $L$ capillary lumen. $\quad \times 14,000$

for PHI (1-15) was also recognized along the thin layer of connective tissue underlying the secretory units. Furthermore, a prominent immunoreactivity for PHI (1-15) was closely related with the blood capillaries (Fig. 3a, b). The distribution of the PHI (1-15)-like immunoreactive fibers was included in that of the AChE-positive fibers. In an identical section, in fact, the reactive portions for $\mathrm{AChE}$ and PHI (1-15) coincided well with each other (Fig. 4a, b). There were, however, some AChE-positive fibers which were not immunoreactive for PHI (1-15).

\section{Ultrastructure}

In this gland, unmyelinated nerve fibers were found to terminate frequently around capillaries underlying the secretory unit. Free nerve endings contained a mixture of synaptic vesicles and dense core granules
(Figs. 5, 6). Small clear vesicles of roundish profile predominated, while large dense core granules, 100 $-150 \mathrm{~nm}$ in diameter, were scattered among them (Fig. 6). The nerve terminals approached the capillary endothelium at a distance of about $450 \mathrm{~nm}$ (Figs. $5,6)$. Although the capillary endothelium was rather thick $(700 \mathrm{~nm})$, well-developed, winding channels of considerable caliber $(170 \mathrm{~nm})$ penetrated it (Figs. 5, $6)$.

\section{DISCUSSION}

The histochemistry for the detection of monoamine and $\mathrm{AChE}$ showed quite different distribution patterns for the FIF fibers and AChE-reactive fibers of the Duvernoy's gland in the present investigation. The innervation by FIF fibers was mostly restricted to the area around the arteries distributed in the 


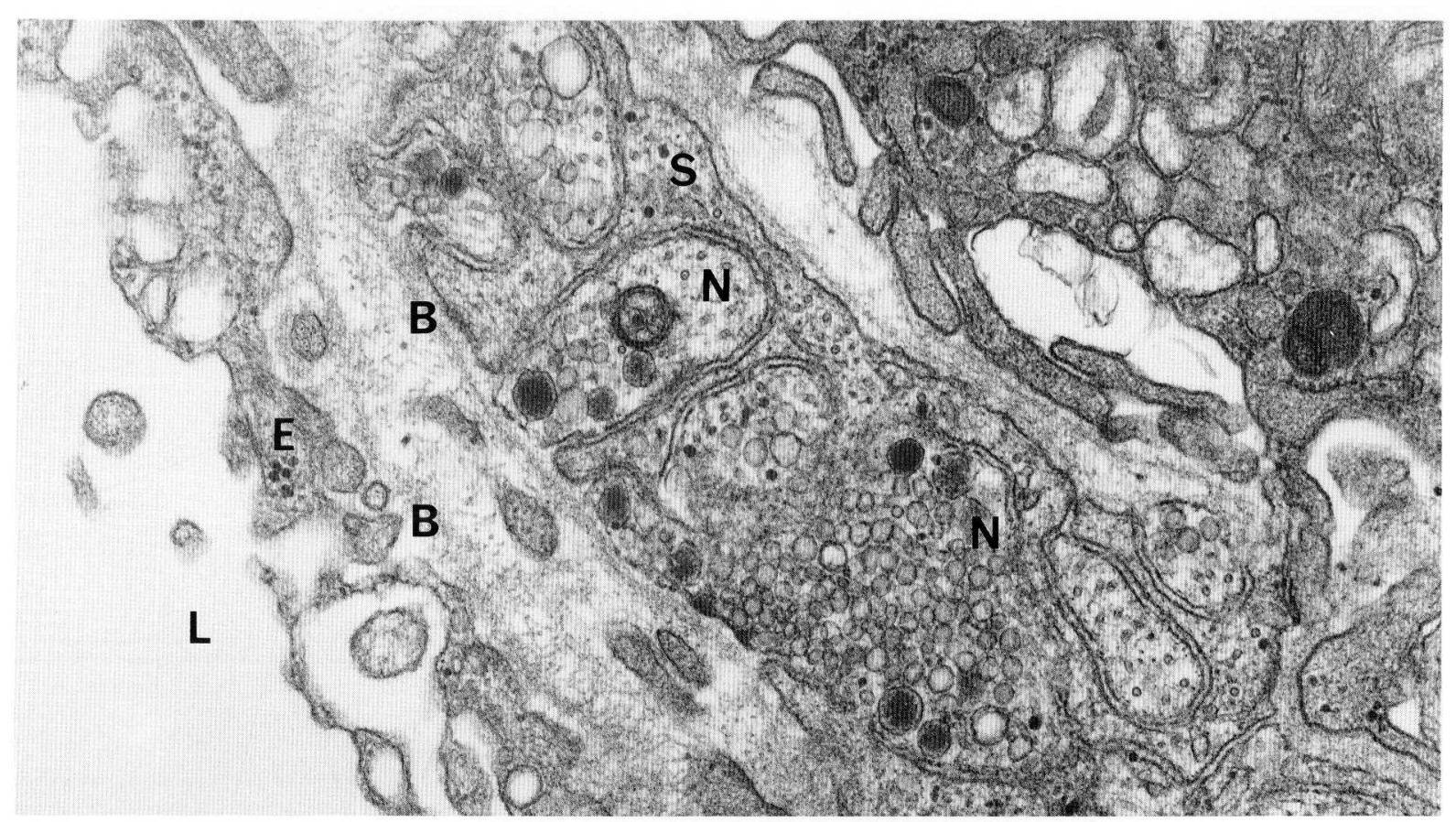

Fig. 6. High magnification electron micrograph of the Duvernoy's gland showing axons $(N)$ containing small clear vesicles and large dense-core granules directly facing a blood capillary. Note vesicles and granlules accumulated towards the surface facing the capillary wall. Capillary endothelium $(E)$ shows a modified form of fenestration. $B$ basal laminae, $L$ capillary lumen, $S$ Schwann cell. $\times 37,000$

interlobular connective tissue. The AChE-reactive fibers, in contrast, were abundantly supplied all over the gland, especially to the lobule consisting of secretory units, where none of the FIF fibers were distributed. These results imply that the direct autonomic innervation of the gland is exclusively done by the AChE-reactive fibers.

For detection of some putative peptidergic innervation, immunoreactivity was only definite for PHI (1-15). PHI, consisting of 27 amino acid residues, was originally isolated and characterized by TATEMOTO and MUTT (1981) from the porcine intestine. It was later revealed that PHI and VIP share a common precursor peptide produced by a single messenger RNA (ITOH et al., 1983). In fact, the co-existence of both the peptides in the same neuron has been immunohistochemically indicated in the gut of the rat and pig (YANAIHARA et al., 1983). Although the immunoreactivity for VIP was negative in the present snake species, the co-existence of VIP with PHI in the PHI (1-15)-like immunoreactive nerves of the Duvernoy's gland can be postulated. The reason for the negative immunoreactivity for VIP may be due to molecular variants of epitopes of VIP in the snake.

The distribution pattern of AChE-reactive fibers was comparable with that of PHI (1-15)-like immuno- reactive fibers, and moreover, on identical sections the site of the AChE reactivity coincided with PHI (1 -15)-like immunoreactive fibers, proving that the PHI (1-15)-like immunoreactive fibers are included in the AChE positive fibers. This finding supports the view that acetylcholine and VIP (also possibly PHI) are co-localized in the same neuron (LUNDBERG et al., 1979; for review, see HökfELT et al., 1980).

The accumulation of both AChE reactivity and PHI (1-15)-like immunoreactivity around capillaries in the lobule agrees with the ultrastructural features of nerve endings in the pericapillary spaces. Each free nerve terminal contained small, clear vesicles and large, dense core granules, which most probably include acethylcholine and VIP/PHI, respectively.

Structural and neurophysiological analyses of the innervation of oral glands including the Duvernoy's gland in snakes remain inadequate. We have preliminarily reported that nerve fibers in the Duvernoy's gland terminate on the myoepithelial cells surrounding the secretory cells (YoshiE et al., 1982) and also very frequently in pericapillary spaces (FUJITA et al., 1982). The present paper both confirms and more precisely establishes the finding that a large number of autonomic nerve fibers rush to the pericapillary spaces to form free endings, whose ultra- 
structural characteristics closely resemble those observed in the pancreatic islets.

It is well known that the pancreatic islets of various animals are richly supplied by autonomic nerves (Coupland, 1958; Cegrell, 1968; LegG, 1968; WA. TARI, 1968; KOBAYASHI and FUUITA, 1969; FUJITA and KOBAYASHI, 1979). In the canine pancreas, FUJITA and KOBAYASHI (1979) revealed that many of the nerve fibers in the islets form free endings filled with synaptic vesicles and peptidergic type granules in the pericapillary space. On the basis of these ultrastructural findings, it has been suggested that, in the islets, neuronal secretions might be released into the blood stream and carried to exert influence on the exocrine pancreas (FUJiTA and KoBAYASHI, 1979) through the insulo-acinar portal system (FUJITA, 1973; Fujita and MURAKAMI, 1973; OHTANi and Fujita, 1980; OHTANI, 1983; Syed Ali, 1984).

This view suggested by FuJiTA and KoBAyashI (1979) is supported by extensive physiological and pharmacological investigations on the actions of neuronal secretions as well as islet hormones on the exocrine pancreas (SALTER et al., 1957; HASHIMOTO et al., 1971; DOLLINGER et al., 1976; KANNO and SAITO, 1976; KONTUREK et al., 1976; SINGH and WEBSTER, 1978).

Although insular neurosecretion in poikilothermic vertebrates has been less extensively studied, electronmicroscopic and immunohistochemical studies of the pancreas of the rat racer snake, Elaphe quadrivirgata, have revealed that the autonomic nerve terminals are concentrated around blood capillaries in the islet and exhibit VIP-like immunoreactivity (FUJII et al., 1980). An insulo-acinar portal system has also been demonstrated to exist in the same snake (OHTANI et al., 1983).

Because the ultrastructural characteristics of free nerve endings in the pericapillary space of the Duvernoy's gland closely resemble those observed in the pancreatic islets, the present findings favor the view that nerve terminals may release their secretions preferably into the capillary blood rather than primarily to the adjacent secretory cells. In contrast to the case with the pancreas, however, the extent of influence of the neurosubstances as well as their target organs is not known for the Duvernoy's gland.

\section{REFERENCES}

Cegrell, L.: The occurrence of biogenic monoamines in the mammalian endocrine pancreas. Acta Physiol. Scand. 314, Suppl: 5-60 (1968).

Coons, A. H., E. H. Leduc and J. M. Connolly: Studies on antibody production. I. A method for the histochemical demonstration of specific antibody and its application to a study of the hyperimmune rabbit. J. Exp. Med. 102: 49-63 (1955).

Corrodi, H., N.-A. HillarP and G. Jonsson: Fluorescence methods for the histochemical demonstration of monoamines: 3 . Sodium borohydride reduction of the fluorescent compounds as a specificity test. J. Histochem. Cytochem. 12: 582-586 (1964).

Coupland, R. E.: The innervation of pancreas of the rat, cat and rabbit as revealed by the cholinesterase technique. J. Anat. 92: 143-149 (1958).

Dollinger, H. C., S. RAPTiS and E. F. Pfeiffer: Effects of somatostatin on exocrine and endocrine pancreatic function stimulated by intestinal hormones in man. Horm. Metab. Res. 8: 74-78 (1976).

Falck, B., N.-A. Hillarp, G. Thieme and A. Torp: Fluorescence of catechol amines and related compounds condensed with formaldehyde. J. Histochem. Cytochem. 10: 348-354 (1962).

FujiI, S., S. Kobayashi, T. Fujita and N. Yanaihara: VIP-immunoreactive nerves in the pancreas of the snake, Elaphe quadrivirgata (Boie): Another model for insular neurosecretion. Biomed. Res. 1: 180-184 (1980).

FuJita, T.: Insulo-acinar portal system in the horse pancreas. Arch. Histol. Jap. 35: 161-171 (1973).

Fujita, T., T. Iwanaga, Y. Kusumoto and S. Yoshie: Paraneurons and neurosecretion. In: (ed. by) D. S. FARNER and K. LEDERIS: Neurosecretion: molecules, cells, systems. Plenum Publ. Corp., New York, 1982. (p. 3-13).

Fujita, T. and S. Kobayashi: Proposal of a neurosecretory system in the pancreas. An electron microscope study in the dog. Arch. Histol. Jap. 42: 277-295 (1979).

Fujita, T. and T. Murakami: Microcirculation of monkey pancreas with special reference to the insulo-acinar portal system. A scanning electron microscope study of vascular casts. Arch. Histol. Jap. 35: 255-263 (1973).

GoEDERT, M., J. I. NAGY and P. C. EMSON: The origin of substance $P$ in the rat submandibular gland and its major duct. Brain Res. 252: 327-333 (1982).

Hashimoto, K., S. Satoh and O. TaKeuchi: Effect of dopamine on pancreatic secretion in the dog. Brit. J. Pharmacol. 43: 739-746 (1971).

Hökfelt, T., O. Johansson, A. LuUngdahl, J. M. LundBERG and M. SchultZBERG: Peptidergic neurons. Nature 284: 515-521 (1980).

Itoh, N., K. Obata, N. Yanaihara and H. Окамоto: Human prepro- vasoactive intestinal polypeptide (VIP) mRNA contains the coding sequence for a novel PHI-27 like peptide, PHM-27. Nature 304: 547-549 (1983).

JoHANSSON, O. and J. M. LUNDBERG: Ultrastructural localization of VIP-like immunoreactivity in large dense-core vesicles of 'cholinergic-type' nerve terminals in cat exocrine glands. Neuroscience 6: 847-862 (1981).

KanNo, T. and A. SaIto: The potentiating influences of insulin on pancreozymin-induced hyperpolarization and amylase release in the pancreatic acinar cell. J. Physiol. 
261: 505-521 (1976).

KARNovsky, M. J.: The localization of cholinesterase activity in rat cardiac muscle by electron microscopy. J. Cell Biol. 23: 217-232 (1964).

Kobayashi, S. and T. Fujita: Fine structure of mammalian and avian pancreatic islets with special reference to D cells and nervous elements. Z. Zellforsch. 100 : 340-363 (1969).

Kochva, E.: Oral glands of the Reptilia. In: (ed. by) C. GANS: Biology of the Reptilia. Academic Press, London and New York, 1978 (Vol. 8, p. 43-161).

Konturek, S. J., A. Pucher and T. Radecki: Comparison of vasoactive intestinal peptide and secretin in stimulation of pancreatic secretion. J. Physiol. 255: 497509 (1976).

LEGG, P. G.: Fluorescence studies on neural structures and endocrine cells in the pancreas of the cat. Z. Zellforsch. 88: 487-495 (1968).

Lundberg, J. M., T. Hökfelt, M. Schultzberg, K. Uvnäs-W Allensten, C. KöHLeR and S. I. SAID: Occurrence of vasoactive intestinal polypeptide (VIP)like immunoreactivity in certain cholinergic neurons of the cat: evidence from combined immunohistochemistry and acetylcholinesterase staining. Neuroscience 4 : 1539-1559 (1979).

Lundberg, J. M., A. ÄngGiRd, J. Fahrenkrug, T. Hökfelt and V. MutT: Vasoactive intestinal polypeptide in cholinergic neurons of exocrine glands: Functional significance of coexisting transmitters for vasodilation and secretion. Proc. Nat. Acad. Sci. USA. 77: 1651-1655 (1980).

Ogawa, T., S. Yoshie and M. IshiYama: Studies on the oral glands of the Reptilia-I. Light microscopical observations on Duvernoy's gland and another supralabial gland of the snake, Rhabdophis tigrinus. Odontology 69: 151-158 (1981).

Ohtani, 0.: Microcirculation of the pancreas: A correlative study of intravital microscopy with scanning electron microscopy of vascular corrosion casts. Arch. Histol. Jap. 46: 315-325 (1983).

Ohtani, 0. and T. FuJita: Microcirculation of the pancreas with special reference to periductular circulation. A scanning electron microscope study of vascular casts. Biomed. Res. 1: 130-140 (1980).

Ohtani, O., A. Kikuta, A. Ohtsuka, T. Taguchi and T. MURAKAMI: Microvasculature as studied by the microvascular corrosion casting/scanning electron microscope method. I. Endocrine and digestive system. Arch. Histol. Jap. 46: 1-42 (1983).

Polak, J. M. and S. R. Bloom: Neuropeptides in salivary glands. J. Histochem. Cytochem. 28: 871-873 (1980).
Robinson, S. E., J. P. Schwartz and E. Costa: Substance $\mathrm{P}$ in the superior cervical ganglion and the submaxillary gland of the rat. Brain Res. 182: 11-17 (1980).

Salter, J. M., W. F. Davidson and C. H. Best: The pathologic effects of large amounts of glucagon. Diabetes 6: 248-255 (1957).

Singh, M. and P. D. W EBSTER: Neurohormonal control of pancreatic secretion. Gastroenterology 74: 294-309 (1978).

STERnberger, L. A.: Immunocytochemistry. 3rd ed. John Wiley \& Sons Ltd., New York, 1986.

Syed Ali, S.: Angioarchitecture of the pancreas of the cat. Light-, scanning- and transmission electron microscopy. Cell Tiss. Res. 235: 675-682 (1984).

TAтEmoto, K. and V. MUTT: Isolation and characterization of the intestinal peptide porcine PHI (PHI-27), a new member of the glucagon-secretin family. Proc. Nat. Acad. Sci. USA 78: 6603-6607 (1981).

Uddman, R., J. Fahrenkrug, L. Malm, J. Alumets, R. HÅKANSON and F. SundLER: Neuronal VIP in salivary glands: Distribution and release. Acta Physiol. Scand. 110: 31-38 (1980).

W ATARI, N.: Fine structure of nervous elements in the pancreas of some vertebrates. Z. Zellforsch. 85: 291-314 (1968).

Yanaihara, N., K. NokihaRa, C. Yanaihara, T. IwaNAGA and T. FUJITA: Immunocytochemical demonstration of PHI and its co-existence with VIP in intestinal nerves of the rat and pig. Arch. Histol. Jap. 46: 575-581 (1983).

Yoshie, S., M. Ishiyama and T. OGawa: Fine structure of Duvernoy's gland of the Japanese colubrid snake, Rhabdophis tigrinus. Arch. Histol. Jap. 45: 375-384 (1982).

\author{
Dr. Sumio YoshiE \\ Department of Oral Anatomy \\ Nippon Dental University \\ 1-8 Hamaura-cho, Niigata \\ 951 Japan \\ 吉 江 紀夫 \\ 951 新潟市浜浦町 1-8 \\ 日本歯科大学新潟歯学部 \\ 第二口腔解剖学教室
}

